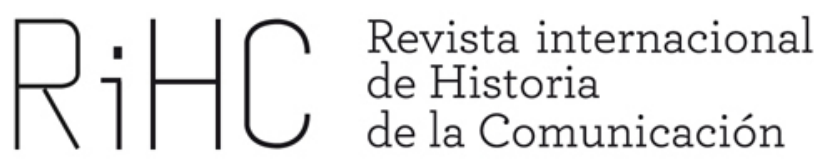

\title{
LOS PRIMEROS MOMENTOS \\ DE LA REVOLUCIÓN ISLÁMICA \\ EN EL DISCURSO PERIODÍSTICO ESPAÑOL (1979)
}

DOI: http://dx.doi.org/10.12795/RiHC.2014.i02.06

Coral Morera Hernández

Universidad de Valladolid

cmorera@hmca.uva.es

Recibido: 18-4-2013

Aceptado: 29-8-2013

Resumen: La revolución islámica ha sido uno de los acontecimientos más trascendentes de los últimos treinta años. Tres décadas después del triunfo del Ayatollah Jomeini en Irán, nos interesa conocer cuáles fueron los discursos emitidos por la prensa española sobre el nacimiento de la Revolución islámica coincidente con la crisis de los rehenes de 1979. Tras la contextualización histórica del período, abordamos la cobertura dedicada por tres diarios de referencia, La Vanguardia, $A B C$ y El País, sobre el triunfo de la Revolución islámica a través del análisis de contenido. Los discursos centrales se centraron en la descripción de una grave amenaza para el equilibrio mundial, en el nacimiento del terrorismo de Estado o en una humillación para los Estados Unidos.

Palabras clave: revolución islámica, rehenes, prensa, EE.UU., terrorismo de Estado. 
Abstract: The Islamic revolution has been one of the most important events of the past thirty years. Three decades after the triumph of Ayatollah Khomeini in Iran, we are interested in knowing the speeches emitted by Spanish press about the beginning of the Islamic revolution coincident with the Iran hostage crisis. From the the historical context analysis of the beginning of the Islamic revolution, we analyze the coverage approached by the three Spanish leading newspapers, La Vanguardia, ABC and EI País. The hostage crisis of 1979 was for the newspapers a serious threat to global equilibrium, the beginning of State terrorism, or a humiliation for the United States.

Keywords: Islamic revolution, hostages, press, United States, State terrorism.

\section{Introducción}

Irán centró la atención de la agenda internacional cuando en noviembre de 1979 se producía uno de los incidentes diplomáticos más graves de los últimos años: la ocupación de la embajada estadounidense en Teherán. Era el último capítulo de un proceso iniciado tres décadas antes y reavivado por el regreso del exilio del ayatollah Jomeini en 1978.

El ingreso en un hospital neoyorquino de quien fuera el último Sha de Persia, Reza Pahlavi, fue el detonante argüido por un grupo de estudiantes revolucionarios seguidores del clérigo chiíta, que secuestraron la embajada estadounidense en Teherán con el propósito de forzar la extradición del Sha ${ }^{1}$. Era el comienzo de la revolución islámica.

Las comunidades chíes vieron en el triunfo de Jomeini un asidero con el que enfrentarse al yugo suní. Después de trece siglos de sometimiento, la victoria del ayatollah sobre el último Sha de Persia significaba un hecho insólito y servía "de fuente de inspiración y talismán para todas las comunidades chiíes dispersas por el mundo", (Martin, 2006: 49).

Hay estudios sobre el análisis histórico y político de la crisis, que se han llevado a cabo con posterioridad a los hechos, así como sobre la lectura que ofrece la revolución islámica después de los atentados del 11 de septiembre, sin embargo, no hay estudios que se ocupen de la cobertura mediática del secuestro de los rehenes que marcó el inicio de la revolución, por lo que la profundización académica del presente trabajo nos parece pertinente. Asimismo, resulta oportuno reflexionar sobre la importancia

\footnotetext{
${ }^{1}$ Entre los secuestradores islamistas se encontraba Mahmud Ahmadineyad, Presidente de Irán desde 2005 hasta 2013.
} 
del fenómeno y la escasa comprensión periodística que de ordinario se presta a los hechos acaecidos en esa parte del mundo².

Nuestro objetivo es conocer la interpretación del fenómeno y los posicionamientos de cada cabecera sobre unos acontecimientos de relevancia, desde el punto de vista histórico y político, y que marcaron un punto de inflexión en Oriente Medio. La revolución islámica iraní añadió más tensión a una zona ya de por sí tensa, provocando la desestabilización de países vecinos al querer ampliar sus zonas de influencia. No desestimamos que la pugna entre chiíes y suníes ${ }^{3}$ fue, y de hecho es, un factor añadido, pero no el único: otros elementos, fundamentalmente de carácter económico y político, parecen más decisivos. Todos estos aspectos, así como el devenir de los acontecimientos hasta la más reciente actualidad, merecen un análisis sobre los discursos de la prensa, en aras de conocer lo acertado o no de sus valoraciones con la distancia de más de treinta años.

Llevamos a cabo una contextualización histórica concreta sobre el contenido y los orígenes, dado que el interés del presente estudio y la naturaleza del mismo, reside en el análisis de las fuentes hemerográficas, no bibliográficas. A partir de una perspectiva metodológica basada en el análisis de contenido, de base cuantitativa y cualitativa, analizamos lo discursivo y lo ideológico expuesto por tres cabeceras de entidad: $L a$ Vanguardia, $A B C$ y El País.

Hemos dividido el corpus de análisis atendiendo a la siguiente clasificación: las noticias; las crónicas y reportajes, es decir, de qué forma interpreta los hechos cada diario, y por último, los artículos de opinión y editoriales en aras de identificar el pronunciamiento oficial de cada rotativo.

Atendiendo a los parámetros propuestos por Thompson (1998), nuestro trabajo se engloba en el siguiente esquema:

1. La producción del discurso: qué se dice.

2. El nivel icónico que incluye a su vez dos apartados:

a. Los aspectos formales: ubicación, espacio, titulares y especiales.

b. Paratexto: imágenes, humor gráfico, mapas, gráficos.

3. La interpretación del discurso: cuáles son las operaciones discursivas de cada cabecera en torno a tres claves de análisis:

a. Descripción

\footnotetext{
${ }^{2}$ Una obra imprescindible para conocer la compleja realidad de Oriente Próximo y desmontar las verdades absolutas asimiladas en Occidente es: SIEFF, M. (2008): The Politically Incorrect Guide to the Middle East, Washington, D.C., Regnery.

${ }^{3}$ Rivalidad que antecede al Islam y que se origina en las civilizaciones de la Antigüedad.
} 


\section{b. Interpretación \\ c. Evaluación}

En el primer apartado tratamos de identificar si el diario realiza una función descriptiva en cuanto a informar. Con respecto al segundo parámetro, en prensa se puede llevar a cabo una interpretación al objeto de explicar o analizar. $Y$ por último consideramos que un diario evalúa cuando más allá de la información o la interpretación, juzga, anticipa o valora los hechos.

Hemos analizado un total de ciento setenta y cuatro informaciones publicadas con ocasión del secuestro de rehenes en la embajada estadounidense en Teherán, que comprenden todo lo que publicó cada diario desde el comienzo de la crisis, a principios de noviembre, hasta finales de diciembre del año 1979. La elección de la prensa viene determinada por el hecho de ser tres cabeceras influyentes y las de mayor difusión del período de análisis, lo que garantiza el espectro ideológico e informativo necesario para alcanzar conclusiones de interés. Los aspectos más llamativos desde el punto de vista cuantitativo están relacionados con el escaso número de editoriales durante toda la crisis, sobre todo si se compara con el número de primeras páginas dedicadas al tema.

Tabla I. Resultados cuantitativos

1a Página/Portada

La Vanguardia

$A B C$

El País

TOTAL
9

3

19
Editorial

2

2
3
Noticias

41

50

45

174

\section{Una aproximación histórica}

Los episodios más conflictivos empezaron en septiembre de 1978 y se extendieron hasta enero de 1979. En febrero de ese mismo año regresó Jomeini a Irán y meses más tarde se desataba la crisis de los rehenes.

El acceso al poder del último Sha de Persia, quien se mantuvo en el mismo durante casi tres décadas, tuvo sus antecedentes en el golpe de Estado contra el nacionalista Musaddaq, ocurrido en 1953, año en que Pahlavi fue proclamado primer ministro. El triunfo del Sha, tal y como apuntan algunos teóricos ${ }^{4}$, vino determinado por la gracia

\footnotetext{
${ }^{4}$ FARZAMNIA (2009) y SCHOLL-LATOUR (1984).
} 
de los Estados Unidos. De esta forma una dictadura sustituía a otra. La dinastía Pahlavi, ajena a extremismos religiosos y políticos, y respaldada por Londres y Washington, fue vista, con poco acierto, como el sistema que implantaría las reformas occidentales necesarias sobre la antigua Persia. La realidad es que el Sha de Pershia, aunque reformista, actuó como un dictador.

Mohammad Reza Pahlavi aplicó años de totalitarismo y represión desde el principio, y se incrementó con la creación en 1957 de la SAVAK (Sazam-e Etealat va Amniyyat-e Keshvar), Organización de Información y Seguridad del país. En estas siglas se resume el terror sufrido por la población a manos de agentes del ejército formados por el Mossad israelí y la CIA.

Uno de los enfrentamientos que protagonizó Pahlavi con el nacionalista Musaddaq poco partidario de las reformas occidentales-, tuvo que ver con el impulso que dio a la nacionalización del petróleo. Sin embargo no fue el único: a principios de 1963 se creó un programa llamado "Revolución del Sha y del pueblo" o "Revolución Blanca". Las intenciones reformadoras del Sha fueron sumando objetores, entre ellos el Frente Nacional y el sector religioso. En este último se encuentra Muhollah Jomeini, quien lideraría dieciséis años después la revolución islámica. El ayatollah, -desconocido por aquel entonces pero popular entre el sector del Frente Nacional-, consideraba inaceptables unas reformas que entendía como una imposición estadounidense y un control sobre Irán. Dos aspectos irritaban especialmente al clérigo chií: el derecho islámico de la propiedad y el derecho de voto de las mujeres. Cuando Reza Pahlavi se proclama emperador en 1967, la oposición al Sha se amplía y aglutina grupos tan diversos como nacionalistas, comunistas y clérigos. Parte del fracaso de la "Revolución Blanca" vino provocada por las medidas drásticas que acometió. Expropió tierras a los clérigos para convertirlas en "shakraks", ciudades modelo. En 1972 el régimen había pasado del autoabastecimiento al colapso absoluto, teniendo que comprar sus productos fuera. Jóvenes desencantados y desesperados buscaron refugio en las mezquitas que el Sha había condenado al destierro.

Los iraníes acudieron a la religión como medio de protesta y en enero de 1978 la publicación de un artículo contra el ayatollah Jomeini, en el exilio desde 1964, precipitó los acontecimientos. La oposición se fue haciendo mayor, a través del chiísmo, y fue el propio Sha quien tuvo que exiliarse en enero de 1979, regresando Jomeini a Irán en febrero de ese mismo año: "La prensa occidental lo reconoció como líder de la oposición iraní y difundió su ideario (...)" (Álvarez Osorio, 2004: 31). Daba comienzo lo que se considera una de las mayores dictaduras religiosas de la historia.

El triunfo de Jomeini, no obstante, no se debió exclusivamente ni al propio ayatollah ni al respaldo mediático, sino a un grupo de hombres de formación occidental pero fieles al chiísmo: Ibrahim Yazdi, Sadegh Ghotbzadeh, portavoz e intérprete del imán; Bani 
Sadr y Sadegh Tabatabai (Scholl-Latour, 1984: 85). También contribuyeron los propios Estados Unidos bajo el mandato de Carter, como sostiene Farzamnia:

El Islam parecía la mejor alternativa, y apoyar a los líderes religiosos el mejor camino para islamizar la revolución que estaba en marcha. [...] y la mejor para defender la región de la expansión comunista. El régimen islámico iraní al que tanto aborrece hoy -refiriéndose a EE.UU.-, llegó al poder, al margen del contexto interno del país, que en ningún caso debe separarse de su contexto externo, gracias a la ineficacia política de Estados Unidos del período Carter y su ceguera ante las consecuencias a largo plazo de apoyar a los líderes religiosos al comienzo de la Revolución Islámica (2009: 149).

El cinco de enero de 1979 tenía lugar la Conferencia de Guadalupe en la que se decidiría el destino iraní entre los líderes norteamericano, francés, británico y alemán: Jimmy Carter, Válery Giscard d'Estaing, James Callaghan y Helmut Schmidt. Cuando se llegó al tema de Irán, los cuatro mandatarios consideraron que había que retirar la confianza al régimen del Sha.

La teoría del "cinturón verde", consistente en que Estados Unidos debía buscar una alternativa para la protección de la zona después del shah, apoyando a los religiosos en la Revolución Islámica, para así contener el avance del comunismo que parecía haberse iniciado con la invasión de Afganistán, estaba a punto de convertirse en una realidad en la Conferencia de Guadalupe (Farzamnia, 2009: 156-157).

\title{
2.1 Cuatro de noviembre de 1979: la humillación al "Gran Satán"
}

\begin{abstract}
A lo largo de cincuenta años, los imperialistas americanos han estado cometiendo delitos en Irán, han vendido el país y arruinado sus costumbres, nuestra juventud ha sido asesinada, los hombres piadosos expulsados, detenidos y muertos. Nosotros no nos dirigimos contra el pueblo americano, sino contra un gobierno americano que continúa combatiendo contra nosotros, que está avivando la guerra civil en el Kurdistán y el Kudistán. Por eso considero que la ocupación de la embajada americana en Teherán es una reacción muy natural, una defensa espontánea y justa de nuestro pueblo.
\end{abstract}

Ayatollah Jomeini ${ }^{5}$

\footnotetext{
${ }^{5}$ Scholl-Latour, 1984: 119.
} 
"El Gran Satán"6, como empezó a referirse Jomeini a EE.UU., era humillado durante cuatrocientos cuarenta y cuatro días con el secuestro de sesenta y seis rehenes norteamericanos y británicos en la Embajada estadounidense en Teherán. Estudiantes y activistas iraníes ocuparon las embajadas estadounidense y británica con el propósito de chantajear al gobierno de los Estados Unidos para la extradición del Sha, hospitalizado en Nueva York ${ }^{7}$.

Carter se había mostrado muy crítico con la política de Nixon relativa a la venta de armas a Chile o Irán que chocaba con su política de Derechos Humanos, por ese motivo diseñó una política de reformas hacia su aliado iraní. Dreyfuss lo relata de la siguiente forma:

Pero después de que el gobierno de Carter dominara el Consejo de Seguridad Nacional en 1977, Estados Unidos inició las presiones sobre el Shah para llevar a cabo tanto reformas políticas como conversaciones con grupos de la oposición, incluidos los líderes religiosos. Esta política acabó debilitando a su régimen, consolidando al ala más conservadora de los religiosos. El objetivo de Estados Unidos mediante estos contactos no era una revolución, sino que muchos de los consejeros tenían la esperanza de que asi la monarquía constitucional, defensora de Estados Unidos se consolidara aún más. (2005: 146).

La enfermedad del Sha, -murió de cáncer en 1980-, es decir, una posible muerte repentina, instó a que Estados Unidos tratara de evitar el triunfo de la rama izquierdista en Irán. Ante el dilema, izquierda o fanatismo religioso, optó por apoyar a la corriente anti-sha de aquellos momentos.

"Dios es grande" y "Muerte al Sha" fueron los gritos que se apoderaron de las calles en aquellos convulsos meses entre septiembre de 1978 y noviembre de 1979. La revolución había triunfado. Jomeini desde el exilio había conseguido movilizar al ejército y a la población.

Las primeras señales de cambio se veían en las calles de Teherán. Se cambiaron sus nombres por los de los imanes mártires shiíes. Casi de inmediato las mujeres fueron "invitadas" a llevar el velo, lo que más tarde se convirtió en una norma, y los hombres a no llevar traje y corbata, símbolo de una modernidad y

\footnotetext{
${ }^{6}$ «El ayatollah Khomeiny ha sido muy explícito: 'Cuando existe un complot, nuestros jóvenes no pueden permanecer con los brazos cruzados. Tenemos que hacer frente a una traición subterránea que se esconde en esta Embajada del gran Satán, América...'». NADAL, C. "El reto del Ayatollah", La Vanguardia, 11-11-1979, p. 17.

${ }^{7}$ Para obtener información sobre el día a día del secuestro, la revolución y sus consecuencias, a cargo de profesionales del periodismo internacional, véase: MOODY, S. C. and the News Staff and photographers of The Associated Press (1981): 444 days. The American hostage story, New York, Rutledge Press.
} 
occidentalización impuestas. (...) Todo empezó a ser "taquti" (demoníaco), expresión que utilizaba Jomeini para demonizar a aquello que no era islámico o a aquello que él, de algún modo, relacionaba con el shah. Pronto la administración se llenó de mullás, religiosos, que ocupaban el puesto de cualquier funcionario (Farzamnia, 2009: 146).

El intento de Estados Unidos por mantener un gobierno moderado en Irán había fracasado y se hizo más evidente con el secuestro de rehenes. Cerca de dos millones de iraníes se concentraron el primero de noviembre para manifestarse en contra del país norteamericano. Aquélla, en principio manifestación antiamericana espontánea, no fue tal en palabras de algunos autores, sino que más bien se debió a una operación organizada con anterioridad (Heikal, 1982:17-21).

El terror se había apoderado de la población iraní. Uno de los responsables de las atrocidades que supuso el régimen islámico en sus comienzos fue Hoyyat ol-Eslam Jaljalí:

Un extremista terrorífico que se cubría la cabeza con una especie de jaula cubierta con una malla para no ser reconocido. Jaljalí no juzgaba, sólo ejecutaba. Las ejecuciones de los que él consideraba del antiguo régimen eran diarias. Los periódicos se encargaban de atemorizar a la población, publicando en sus primeras páginas enormes fotos en color de los cuerpos sin vida de los ejecutados, llevando a pie de foto el relato de si habían muerto en la primera ráfaga, en cuyo caso se describía cómo se les había pegado el tiro de gracia, o si habían dicho algo justo antes de recibirlo (Farzamnia, 2009: 162).

\section{El mundo en peligro, por La Vanguardia}

Cuando existe un complot, nuestros jóvenes no pueden permanecer con los brazos cruzados. Tenemos que hacer frente a una traición subterránea que se esconde en esta Embajada del gran Satán, América.

Ayatolah Jomeini $^{9}$

\footnotetext{
8 Para una profundización sobre la crisis de los rehenes en la versión de algunos de ellos, véase: SICKMANN, R. (1982): Iranian hostage: a personal diary of 444 days in captivity, Topeka, Crawford Press; WELLS, T. (1985): 444 days: the hostages remember, San Diego, Harcourt Brace Jovanovich.

${ }^{9}$ NADAL, C. “El reto del Ayatollah”, La Vanguardia, 11-11-1979, p. 17.
} 
El discurso central de la cabecera catalana advirtió de la amenaza del islamismo. La cobertura abarca la información, el análisis de la evolución de la crisis y las consecuencias de ésta.

En el plano icónico las imágenes publicadas nos llevan a presenciar esa amenaza ${ }^{10}$. Desde las primeras páginas, tanto en volumen como en la posición, parte superior de la página, así como en el objeto mismo fotografiado, el diario quiso resaltar el fanatismo de la revolución liderada por Jomeini y materializada por los estudiantes que mantenían a los rehenes en cautiverio, y por los propios iraníes, seguidores en tropel de las soflamas de líder chiíta. En general son imágenes que muestran lo que es la revolución teocrática.

Al principio de la cobertura el especial se titula: "Ocupación de la Embajada norteamericana en Teherán". Más adelante, con motivo del agravamiento de la crisis, los especiales cambiarán la terminología de "ocupación" a "provocación" contra los Estados Unidos, mientras combinan otros vocablos como "el huracán desencadenado por Khomeini" y "el aumento de la ebullición en el mundo islámico".

El mundo islámico es para La Vanguardia un interrogante peligroso. Los términos más utilizados en titulares, de carácter mayormente informativo, se refieren a "peligro", "tensión", "gravedad" y "fricción", en manos de un único responsable: "un terrorista llamado Khomeini" ${ }^{11}$.

Nos ocupamos a continuación de las crónicas del corresponsal en Estados Unidos, Ángel Zúñiga, que destacan por un estilo vehemente, si bien analizamos también algunas informaciones firmadas por otra cronista.

Entre lo malo, -la política estadounidense allí-, y lo peor, -la revolución islámica-, apeló a la coherencia, es decir, a Estados Unidos. Estamos ante "acciones intolerables", de lo que está resultando una "flagrante barbarie", un "espectáculo insólito" en manos de "gente incivilizada". El asalto a la embajada estadounidense, "no tiene justificación". La crítica que hoy recibe EE.UU. reside en haber apoyado a un aliado "que les había servido a manos llenas", sin bien, "son hechos, me atrevería a decir, delictivos, que se cometen impunemente en un mundo que ha perdido la brújula navegando por los mares más azarosos de la brutalidad"12.

La crítica hacia Europa está presente en lo que considera "una gestión más bien platónica" ${ }^{13}$. Se otorga al presidente Carter un margen de confianza en la gestión de la

\footnotetext{
${ }^{10}$ Véase Anexo final con las ilustraciones de todas las portadas que dedicó a los hechos: La Vanguardia, $08 / 11 / 1979$, p. $1 ; 09 / 11 / 1979$, p. $1 ; 15 / 11 / 1979$, p. $1 ; 17 / 11 / 1979$, p. $1 ;(22 / 11 / 1979)$, p. 1.

${ }^{11}$ MASANA, Ma D. “Un terrorista llamado Khomeiny", La Vanguardia, 08-11-1979, p. 23. Se conserva la terminología original de los términos empleados por cada periódico para los nombres propios y vocablos extranjeros.

${ }^{12}$ ZÚÑIGA, A., “Nueva York: Chantaje inaceptable”, La Vanguardia, 06-11-1979, p. 21.

${ }^{13}$ A. G., "La CEE protesta ante el Gobierno Irán”, La Vanguardia, 10-11-1979, p. 17.
} 
crisis, para conforme avancen los hechos, censurar su gestión ante la falta de autoridad y decisión.

El islamismo no es un problema que ataña solamente a Estados Unidos, sino a toda la comunidad internacional, dado que la guerra que se acaba de iniciar es contra el mundo: "El ayatollah Khomeiny lo ha expuesto en una frase significativa. No es una lucha entre Estados Unidos e Irán, sino una lucha entre el Islam y la blasfemia" ${ }^{14}$. Esta es la realidad de una revolución y las consecuencias que conlleva:

En el proceso revolucionario de Irán, este es el punto más complicado, mayormente por cuanto los santones que gobiernan a los desgobernados iraníes, son quienes más alientan hechos como el actual. Ninguna nación, medio civilizada, se hubiera atrevido a tanto. Así se explica la dimisión del primer ministro Bazargan, que en medio de aquel tumulto, era la única voz sensata que pretendía hacerse oir ${ }^{15}$.

Estamos ante una revolución que viola las leyes internacionales y todos los principios de las relaciones entre los países, y que además se permite chantajear al mundo a costa del petróleo. Como colofón de tanto despropósito, las imágenes de los rehenes humillados dan la vuelta al mundo. Esta es la forma en la que se entra en un caos sin orden ni autoridad: "Ahora se dedican a humillar a algún rehén haciéndole aparecer con venda en los ojos entre la plebe revolucionaria para animar sus pasiones. No se podía caer más"16. "El mundo ha perdido la conciencia de sí mismo. Estamos ante el caos en directo del terror, por el terror mismo" ${ }^{17}$. "Ya hemos visto que se intenta gobernar como en un pasado remoto basándonos en la religiosidad de las gentes y en el libro sagrado del Corán"18.

¿Y quién es el causante de esta "orgía irresponsable"? ${ }^{19}$. En primer término Khomeini, pero también, el presidente Jimmy Carter, por su pésima gestión, unos aliados europeos incapaces de reaccionar, y unos organismos internacionales, léase ONU y CEE, que miran para otro lado. Estamos ante un líder chiíta, un "fanático apasionado que debe pensar que la batalla de Lepanto fue anteayer" ${ }^{20}$. Así es este clérigo exaltado, quien tras un año en el poder sigue recurriendo a "juicios sumarísimos", tales

\footnotetext{
14 ZÚÑIGA, A. "Nueva York: Aparente atonía norteamericana ante las algaradas y los insultos", La Vanguardia, 24-11-1979, p. 16.

${ }^{15}$ ZÚÑIIGA, A. "Nueva York: Carter ante un problema de difícil resolución”, La Vanguardia, 07-11-1979, p. 17.

${ }^{16}$ ZÚÑIGA, A. "Nueva York: el ex Sha propone abandonar el país”, La Vanguardia, 09-11-1979, p. 17.

${ }^{17}$ ZÚÑIGA, A. "Nueva York: Un iraní mata a un estudiante norteamericano en Denver", La Vanguardia, 13-11-1979, p. 23.

${ }^{18}$ ZÚÑIGA, A. "Nueva York: Oleada de protestas en las universidades norteamericanas", La Vanguardia, 17-11-1979, p. 15.

19 ZÚÑIGA, A. "Nueva York: el ex Sha propone abandonar el país”, La Vanguardia, 09-11-1979, p. 17.

${ }^{20}$ ZÚÑIGA, A. "Carter exige la liberación inmediata de todos los rehenes", La Vanguardia, 20-11-1979, p. 23.
} 
como las ejecuciones de mujeres embarazadas acusadas de adulterio, las flagelaciones públicas y reclamando la entrega de un hombre sentenciado a muerte por cáncer. Así es como el Islam enseña a aplicar la ley del Talión ${ }^{21}$.

La falta de actuación y condena de los principales organismos internacionales provoca la queja del cronista. Ante unos hechos de semejante gravedad que vienen determinados, no sólo por la violación de las normas básicas de la convivencia y la diplomacia, sino por el mal estilo de los actos, Naciones Unidas responde con hipocresía y falta de acción ${ }^{22}$. La CEE, por su parte, no acompaña "amenaza alguna", no sólo porque "ése no es el estilo de las democracias europeas" sino por su debilidad militar y porque es difícil imaginar "qué tipo de presión pueden hoy ejercer estos nueve países tan dependientes del petróleo", sobre un Estado que a día de hoy "ha dejado de existir"23.

Otro núcleo argumental que nos interesa destacar es el aislamiento internacional que sufre Estados Unidos por culpa de unos aliados desagradecidos. El discurso es claro y contundente.

Hasta este momento, la Alemania occidental ha sido el único país que ha tomado una decisión, cerrando su Embajada en Teherán, que sólo funcionará para casos urgentes. Si se vulneran todas las reglas del juego, que exista una solidaridad entre los países civilizados. Hechos, mejor que palabras. [...] Francia e Inglaterra sobre todo, deberían ya haber tomado cartas en el asunto, algo más que una interpelación en el Parlamento, colocándose al lado de Estados Unidos, país al que deben lo que son ${ }^{24}$.

Si el máximo responsable de esta crisis es Khomeini, no lo es menos Carter, consentidor de una situación de máximo peligro. $Y$ todo debido a los "dichosos derechos humanos" que no hicieron sino entorpecer en los primeros momentos de la crisis:

¿Hasta cuándo puede llegar la debilidad de la jefatura de este país en el mundo? ¿Hasta dónde pueden continuar los prejuicios amamantados en la época del New Deal, y que se ha visto ofrecen ya escasas perspectivas, si alguna? [...]. Su llegada a este país ha determinado la brutalidad de los hechos siguientes. Fueron el multimillonario banquero David Rockefeller y el ex secretario de Estado, señor Kissinger, quienes humanamente consiguieron del secretario de Estado, señor

\footnotetext{
${ }^{21}$ MASANA, Mã D. "Un terrorista llamado Khomeiny”, La Vanguardia, 08-11-1979, p. 23.

${ }^{22}$ ZÚÑIIGA, A. "Nueva York: Carter ante un problema de difícil resolución”, La Vanguardia, 07-11-1979, p. 17.

${ }^{23}$ A. G. "La CEE protesta ante el Gobierno Irán”, La Vanguardia, 10-11-1979, p. 17.

${ }^{24}$ ZÚÑIIGA, A. "Nueva York: el ex Sha propone abandonar el país”, La Vanguardia, 09-11-1979, p. 17.
} 
Vance, el visado de entrada del Sha en este país para ser tratado de su grave y seguramente mortal enfermedad ${ }^{25}$.

Incertidumbre, falta de mando, de decisión y de autoridad, son los términos que mejor definen la gestión de la crisis. Crisis, que hubiera sido gestionada con más contundencia por el bloque del Este: "Vamos a contar que a la Unión Soviética se le hubiese asaltado la embajada y mantuvieran rehenes rusos. Seguro que Moscú hubiese estado mucho más de acorde con la urgencia del momento"26.

Nos ocupamos ahora del análisis de los editoriales y los artículos de opinión. Entiende Carlos Nadal, uno de los articulistas que más se ocupa de la crisis, que el secuestro de rehenes no es más que la consecuencia lógica de una cadena de errores por parte de los Estados Unidos ${ }^{27}$. Para el articulista han sido precisamente Occidente en general, y los EE.UU. en particular, quienes se han desentendido de sus responsabilidades con respecto al orden mundial y han dado pie a este espectáculo de "irracionalismo" y "barbarie". No hay unas críticas lacerantes hacia el Islam, diríase incluso que destaca sus virtudes, sino que son otras causas, más relacionadas con el imperialismo y menos con la religión, las que han desatado “los brotes de ira santa de Irán o de La Meca”28.

Desde los editoriales advertimos la exposición de la gravedad de una situación que a partir de ahora puede poner en peligro al mundo, desde un discurso que señala que no se trata solamente de que las iras religiosas de un imán mantengan a Irán en vilo, sino que con la revolución islámica que ahora comienza, caracterizada por el fanatismo del ayatollah de Qom y sus seguidores, se acaba de crear "una situación extremadamente delicada de orden internacional ${ }^{29}$.

El Golfo Pérsico se convierte a partir de ahora en el epicentro de las presiones y convulsiones de un mundo en tensión, de ahí que asistamos a hechos de imprevisibles pronósticos. En treinta años de luchas entre árabes e israelíes no habíamos presenciado una situación de tal gravedad. Estamos ante una crisis honda por su amplitud geográfica, económica y estratégica. Por ello, insiste en recordar, que la preocupación debe ir más allá de las soflamas del clérigo chiíta: el centro de la crisis es el nacimiento de una dialéctica revolucionaria que esconde una estrategia política muy eficaz, hasta ahora desconocida:

La revolución islámica del ayatollah Khomeiny ha activado una energía pasional de incalculables posibilidades en el orden político. Millones de personas, decenas

\footnotetext{
${ }^{25}$ ZÚÑIGA, A. "Nueva York: Un iraní mata a un estudiante norteamericano en Denver", La Vanguardia, 13-11-1979, p. 23.

${ }^{26}$ ZÚÑIGA, A. "Carter pide protección para las embajadas norteamericanas”, La Vanguardia, 22-11-1979, p. 18.

${ }^{27}$ NADAL, C. "El reto del Ayatollah", La Vanguardia, 11/11/1979, p. 17.

${ }^{28}$ NADAL, C. "Ímpetu y debilidad del Islam”, La Vanguardia, 25/11/1979. p. 17.

29 “Acciones intolerables", La Vanguardia, 06-11-1979, p. 5, (editorial).
} 
de países, inmensas extensiones territoriales son sin duda fácil caja de resonancia para lo que está ocurriendo en Teherán, para un duelo sorprendente entre dos conceptos de la legalidad, la justicia, la razón y el poder que no tienen ningún punto común de referencia. [...] Las guerras de Corea, Argelia y Vietnam entraban en la lógica de un orden de valores, eran el choque frontal y abierto en el que se barajaban conceptos perfectamente comprensibles de hegemonía, independencia, nacionalismo, libertad; o comunismo y democracia, etc. En los alarmantes acontecimientos que se están viviendo ahora en Irán, Arabia o Pakistán este tipo de valoraciones no sirve. El fenómeno religioso ha irrumpido en el difícil entramado de poderes, ideologías, esferas de influencia, de nuestro mundo con la temible premonición de que todo puede estar sujeto a alteraciones profundas $^{30}$.

La realidad es que estamos ante un régimen peligroso y retrógrado, en manos de alguien, que apelando a un poder espiritual, ya ha protagonizado casi setecientas condenas a muertes, y cuyos tribunales juzgan y torturan tanto a miembros del SAVAK, como a adúlteras y homosexuales ${ }^{31}$.

\section{El terrorismo de Estado y la decadencia del gigante, por $A B C$}

Encontramos tres discursos en la cobertura del diario $A B C$ : el nacimiento del terrorismo de Estado, la pérdida de influencia de los Estados Unidos en el mundo y la deficiente gestión de la crisis por parte del país norteamericano.

Atendiendo al plano visual destacamos la menor presencia de elementos gráficos, dado que sólo encontramos dos portadas en torno a los hechos, y ninguna fotografía en páginas interiores ${ }^{32}$. Los titulares, de carácter informativo, hacen hincapié en la figura de Jimmy Carter, de Washington y en menor medida, casi residual, del líder chiíta Jomeini. La uniformidad con respecto al encabezamiento de los especiales se enmarca en "La crisis IRAN-USA" y "La crisis USA-IRAN".

Nos ocupamos a continuación de las crónicas del corresponsal en Estados Unidos, José María Carrascal, y después del único editorial sobre el que pueden obtenerse conclusiones de interés.

\footnotetext{
30 "Crítico desafío", La Vanguardia, 22-11-1979, p. 7, (editorial).

31 “Acciones intolerables", La Vanguardia, 06-11-1979, p. 5, (editorial).

${ }^{32} A B C$ no incluía fotografías interiores en aquella época, tan sólo algunos dibujos y humor gráfico.
} 
Lo difundido a través de las crónicas nos sitúa ante una revolución desatada por el ayatollah, que está destruyendo la imagen de Estados Unidos en el mundo. Es una crisis grave para el equilibrio mundial, impredecible y angustiosa, en la que Estados Unidos se ha convertido en una nación de "cuarto orden" ${ }^{33}$.

¿Qué se pretende?: humillar al "gran Satán" o lo que es lo mismo, evitar la Occidentalización. Tal es la habilidad de los musulmanes en este empeño, y tal la pésima actuación llevada a cabo por Carter, que nos hallamos, ante el dilema: Oriente u Occidente. El llamado a poner orden en este caos es Estados Unidos.

El Sha se ha convertido en el símbolo de lo que detestan: Occidente, "con toda la secuela de laicismo, mecanización y corrupción. Y los Estados Unidos, en la definición del 'ayatollah', son 'la madre del mal'":

Nada de esto se entiende si nos atenemos a las palabras que se cruzan, cada vez más contradictorias, pero aparece muy claro si vamos al fondo de la crisis. El último objetivo iraní -y estoy citando al catedrático de Cultura Islámica de Harvard- no es echar la mano al enfermo Sha. Su objetivo último es humillar a los Estados Unidos, demostrar su vulnerabilidad e impotencia. [...] Hay que borrar su influencia en su país y en el mundo. Hay que demostrar que ese gigante, cuya riqueza, potencia y estilo de vida todos admiran, es en realidad un fantoche sin nervio, incapaz de resistir el impacto revolucionario de un país dispuesto a morir por lo que cree. Hay que demostrar, en suma, que los Estados Unidos no son un modelo a imitar. Esto es lo que hay tras tantos insultos, amenazas, propuestas y reuniones del Consejo de Seguridad, lleguen a celebrarse o no ${ }^{34}$.

¿Cómo hemos llegado hasta aquí? El Sha tuvo mucho que ver en todo esto: "Todo fue demasiado rápido, demasiado brusco, demasiado corrupto, demasiado mal planeado. El pueblo iraní no fue capaz de digerirlo y surgió una añoranza de lo viejo, de lo anterior, de lo sencillo, de la pureza, de lo autóctono". Jomeini, convertido en un símbolo de virtud y de pasado, amortiguaba "tanto vértigo, cambio y angustia" 35 . Aquel caos que ahora se cierne sobre Irán, y por ende, sobre el mundo, tiene gran lógica y coherencia: Jomeini aprovechó el respaldo obtenido por la prensa y por la opinión pública estadounidense y ahora recoge sus frutos.

En la sucesión de tan graves acontecimientos, -sobre los que se impone la exigencia de que la primera potencia actúe-, el diario no se detuvo tanto en la evolución de los

\footnotetext{
33 "Respetuosamente, los Estados Unidos se han convertido en una nación de cuarto orden. Por muy superpotencia que sea, ¿cómo van a defender a los demás si no saben defender a sus propios súbditos?". CARRASCAL, J. M. "Impotencia de la administración Carter frente a Jomeini”, ABC, 09-111979, p. 15.

${ }^{34}$ CARRASCAL, J. M. "Maniobras en torno a la reunión del consejo de seguridad", ABC, 27-11-1979, p. 15.

${ }^{35}$ CARRASCAL, J. M “Teherán amenaza con adelantar el proceso de los rehenes”, ABC, 25-11-1979, p. 13.
} 
hechos, sino en el origen de la crisis y en las consecuencias de la misma. Con grandes dosis de sarcasmo, advirtió que asistíamos a una guerra santa en la que sus líderes rezaban en diferentes credos:

Carter ha llamado a Jomeini promotor del terrorismo. Jomeini, a Carter, sencillamente, ladrón. Luego, ambos se retiraron a orar, uno en la mezquita de Qon [sic], otro en la catedral de Washington. Son dos hombres piadosos, honestos, firmemente convencidos de la moralidad de su política. Pero con una diferencia clave: uno tiene un enorme sentido del poder. El otro, desconfía de él y es reacio a usarlo. No hace falta decir quién es quién. Jomeini encabeza una nación vieja, revitalizada por la fiebre revolucionaria. Carter, una nación joven, aventajada por el peso imperial, que no sabe cómo llevar ${ }^{36}$.

Carter, la potencia estadounidense e incluso sus ciudadanos, son el núcleo del segundo discurso que destacamos en nuestro análisis. Estados Unidos bajo el mandato Carter, gracias a su paciencia, diplomacia y racionalidad, está arrinconado por Jomeini. El carácter blando de Carter es en buena parte la razón de la crisis: "un hombre honesto y bienintencionado, que abomina el uso de la fuerza. Por eso mismo le hace presa fácil de los fanáticos, los ambiciosos y los resentidos, que tratan de reafirmar su poder humillando a Norteamérica" ${ }^{37}$. Y todo ello sin tener en cuenta no sólo la gravedad de una situación que desestabiliza el precario equilibrio mundial, sino actuando torpemente ante el nuevo fenómeno que se cierne sobre el mundo: el terrorismo de Estado. Veamos cómo lo expuso $A B C$ :

Washington está actuando como si se encontrara ante típicos terroristas: prolonga el sitio, habla con ellos, establece todos los canales de comunicación posibles, espera que surjan los naturales lazos entre ellos y los rehenes. Ir quitando, en fin, poco a poco la espoleta a la bomba a base de paciencia y labia. Es lo que ha dado hasta ahora mejor resultado en este tipo de casos. Pero hay dos elementos nuevos: no se trata del terrorismo típico, sino de terrorismo de Estado. Los estudiantes iraníes tienen el respaldo de sus autoridades. No están sometidos a las típicas presiones del encierro y del cerco policial, sino que pueden entrar y salir de la Embajada cuando quieran, para ser coreados por la multitud. No sólo se creen del lado bueno, sino que son confirmados a cada momento en él ${ }^{38}$.

El clérigo chiíta se está aprovechando de esta situación, con una oratoria que no merece comentarios ${ }^{39}$ y todo ello por culpa de un presidente débil y de un pueblo que

\footnotetext{
${ }^{36}$ CARRASCAL, J. M “Carter y Jomeini intercambian insultos”, $A B C, 17-11-1979$, p. 15.

37 CARRASCAL, J. M. "Washington apela al tribunal de la Haya”, $A B C, 30-11-1979$, p. 15.

${ }^{38}$ CARRASCAL, J. M. "Washington pide la mediación de la ONU", $A B C, 10-11-1979$, p. 1.

39 «En el nombre de Dios, el misericordioso, el compasivo, América, América, imuerte para tus complots! La sangre de nuestros muertos gotea de tus garras. Los Estados Unidos son el enemigo número uno de la Humanidad y del pueblo iraní. Bajo el pretexto de que el depuesto Sha está enfermo,
} 
se deja intimidar: "No hace falta que les torturen o amenacen. Basta que les sometan a una norma dura y les bañen en propaganda para que se desmoronen" ${ }^{40}$.

La gestión estadounidense está siendo nefasta, y la situación general kafkiana: Jomeini sigue lanzando soflamas sobre su movilización nacional contra el poder satánico de los Estados Unidos mientras a éstos se le niega el uso de la palabra ante el Consejo de Seguridad por "temor a ofender a los iraníes" ${ }^{41}$.

[...] se equivocaría quien imaginase a este país afilando la espada. No. El sentimiento más extendido es la frustración, la impotencia, el decirse ¿qué podemos hacer? Después de Vietnam, del Watergate, de las acusaciones contra la CIA y de las confesiones en voz alta, este país está desarmado moralmente. Es incapaz de reaccionar. Y Carter no es el hombre para ello. Al revés, es la consecuencia de ello. [...] Naturalmente, esto no puede seguir así indefinidamente. Un día, los Estados Unidos van a decir basta, y mejor no pensar en lo que seguirá. Pero no bajo este presidente, que representa, más que el pueblo americano, la mala conciencia americana hacia el mundo ${ }^{42}$.

Y no culpa el diario a sus aliados de la falta de confianza y apoyo a Estados Unidos en un momento de crisis como sí hace La Vanguardia, sino que es la propia potencia norteamericana la que se ha granjeado la falta de respaldo:

Su actitud tiene la dura lógica que han exhibido durante toda la crisis. Lo amargo para Washington es encontrarse sin el apoyo de países como Francia y Kuwait que han preferido no ofender al 'ayatollah'. Si alguien quiere una prueba del descenso vertiginoso de la influencia de los Estados Unidos en el mundo, ahí la tienen. Ya no se está con ellos ni siquiera cuando tienen razón. Pero es que han tratado tan mal a sus amigos, que hay que pensárselo mucho antes de ser uno de ellos ${ }^{43}$.

Con respecto al discurso editorial, destacamos la descripción de una "revolución de base religiosa y definición antiamericana": "Por una jerarquía y orden de causa a efecto puede decirse que la crisis en el Oriente Medio es, antes que militar, política, antes que política, ideológica y antes que ideológica, rigurosamente teológica” ${ }^{44}$.

le acogen. ¡Exigimos la entrega del gran criminal!». CARRASCAL, J. M. "El Consejo de la Revolución asume el gobierno en Irán", $A B C, 07-11-1979$, p. 12.

${ }^{40}$ CARRASCAL, J. M. "Jomeini acepta la mediación del ex embajador Andrew Young", ABC, 21-11-1979, p. 13.

${ }_{41}^{41}$ CARRASCAL, J. M. “Norteamérica abocada a una situación de fuerza”, ABC, 28-11-1979, p. 15.

${ }^{42}$ CARRASCAL, J. M. "Frustración norteamericana en el día de acción de gracias", ABC, 23-11-1979, p. 13.

${ }^{43}$ CARRASCAL, J. M. "Norteamérica abocada a una situación de fuerza", $A B C$, 28-11-1979, p. 15.

44 "Una tempestad de arena coránica", $A B C, 23-11-1979$, p. 2, (editorial). 


\section{Carter: el triunfo de una gestión, por EI País}

La cobertura de El País con respecto al tema adolece de uniformidad en los mensajes difundidos, siendo éstos diferentes en función del género desde el que se emitan. Es decir, se sigue una línea informativa distinta para las primeras páginas, editoriales e información interior. Desde las noticias no se incorporan datos según los cuales los hechos puedan considerarse como de extrema gravedad, sin embargo desde algunos editoriales sí se habla de una revolución islamista en expansión, totalitaria y grave ${ }^{45}$.

El elemento icónico visual, así como la redacción de los titulares, le separan del discurso emitido por los otros dos diarios. Más que ilustrar la crisis iraní, parece querer mostrar la humillación que está sufriendo Estados Unidos. No se detecta asimismo que el diario condene al imán chiíta ni el comportamiento de los secuestradores. Este aspecto se detecta en la primera página publicada al comienzo de la crisis, en la que mientras que La Vanguardia hablaba de "ocupación de la embajada norteamericana en Teherán”, el diario madrileño se refirió a “Decoran la embajada” ${ }^{46}$ en el pie de foto publicado en la primera página, y lo acompañaron de un comienzo de texto que mantenía la misma línea: "Estudiantes iraníes cuelgan retratos del ayatollah Jomeini en las paredes de la embajada norteamericana en Teherán". La misma tendencia parece observarse en cuanto a que las medidas del ayatollah aparecen en los antetítulos y no en titulares como ocurre en los otros dos diarios, mientras que las medidas que adopta EE.UU. con respecto a los estudiantes iraníes en Norteamérica o el bloqueo de alimentos, por citar dos ejemplos, sí son destacadas en los titulares: "Teherán suspende los suministros petrolíferos a dos compañías norteamericanas"; "Compás de espera en la crisis Irán-Estados Unidos" ${ }^{47}$.

Las fotografías publicadas exhiben varias imágenes de iraníes quemando banderas norteamericanas o ante un mural de caracterización negativa hacia Estados Unidos. La figura de Carter parece desdibujarse de la debilidad y falta de liderazgo mostrada en los otros diarios, para decantarse por un líder enérgico que apunta con su dedo índice $^{48}$.

Los titulares más graves figuran en noticias que tienen a Carter como protagonista tanto en texto como en foto, nos estamos refiriendo a aquellos que expresan la "peligrosa escalada en la crisis iraní". Por el contrario, los titulares menos dramáticos

\footnotetext{
${ }^{45}$ Cfr. "Irán, la revolución en expansión”, El País, 08-11-1979, p. 8, (editorial); "La crisis de Irán”, El País, 17-11-1979, p. 6, (editorial); “El síndrome de Teherán”, El País, 05-11-1979, p. 8, (editorial).

${ }^{46}$ Cfr. El País, 06-11-1979, p. 1.

${ }^{47}$ GONZALEZ YUSTE, J. El País, 16-11-1979, p. 3.

${ }^{48}$ Cfr. El País, 10-11-1979, p. 1; 11-11-1979, p. 1; 15-11-1979, p. 1.
} 
se centraron en Jomeini, quien aparece tanto en el texto como en la imagen: "Favorable acogida en Washington al anuncio de la liberación parcial de rehenes" ${ }^{49}$. Encontramos asimismo cierta alteración en la información publicada con motivo de la liberación de los primeros rehenes: "Los rehenes no norteamericanos de la embajada de Irán, liberados" ${ }^{\prime 50}$. La información no se ajusta a la verdad en cuanto a que los liberados sí eran estadounidenses, concretamente las mujeres y los ciudadanos de raza negra. En la misma información puede leerse un antetítulo con el siguiente texto: "Jomeini advierte que no podrá evitar la muerte de los cautivos si Estados Unidos interviene militarmente". Se refirió a una posible intervención norteamericana de forma recurrente y con bastante probabilidad, algo que no se advierte de forma explícita en los otros dos diarios. Parece advertirse cierta intencionalidad al tratar de exculpar a Jomeini de las futuras acciones y volcar toda la responsabilidad de lo que ocurra en manos de Jimmy Carter. En general, hallamos titulares caracterizados por restar gravedad a los acontecimientos.

Otro aspecto que analizamos en este apartado se refiere a la inclusión de humor gráfico con motivo de la crisis de los rehenes. La Vanguardia y $A B C$ no incluyeron viñetas con motivo de la crisis, mientras que El País sí lo hizo. El tono de éstas, sigue una relación directa con respecto a la humillación que está sufriendo Estados Unidos ${ }^{51}$.

Nos ocupamos a continuación de las crónicas de los corresponsales, Juan González Yuste y Félix Bayón, y de las informaciones publicadas en páginas de "Internacional". La característica principal del discurso gira en torno a dos aspectos: por un lado, la ausencia de condena expresa a la acción del imán iraní, y por otro, la falta de distancia con la retórica y agresividad de la oratoria del clérigo chiíta ni con los principios que su revolución predica. El lenguaje fue utilizado de manera que, si bien se menciona que se trata de una crisis que se ha desatado en Irán, se evitan las alusiones a Jomeini.

Se detecta asimismo cierto énfasis por ensalzar los valores que representa la cultura islámica así como un respaldo implícito a los secuestradores. Algunas informaciones cubren con aire romántico la revolución islámica:

De día, como de noche, la muchedumbre se ha apoderado de todo el barrio, de las calles y de las paredes, de las aceras y de los escaparates, de los edificios en construcción y de algunos descampados (...). Cada uno trae su tributo y fija su retrato del "guía" si consigue encontrar algún trozo de pared inexplicablemente libre. Los muros de ladrillo rojo de un kilómetro de largo que rodean la embajada norteamericana han quedado prácticamente inutilizados: mástiles han sido introducidos en las grietas para poder colgar más retratos del imán, mientras un

\footnotetext{
${ }^{49}$ Cfr. 18-11-1979, p. 2.

${ }^{50}$ Cfr. 23-11-1979, p. 1.

${ }^{51}$ En ambas viñetas figura Jomeini orinando sobre Carter. El País, 10-11-1979, p. 3; 16-11-1979, p. 3. Véase Anexo final.
} 
gran cartel que representa al jefe religioso tapa la fachada hasta el segundo piso de la cancillería. Los manifestantes escriben ahora sobre la calzada ${ }^{52}$.

El presidente demócrata fue presentado como un líder enérgico que adoptaba medidas eficaces a lo largo de la crisis:

Los líderes laborales interrumpieron con aplausos en numerosas ocasiones al presidente, especialmente, cuando éste dijo que el gobierno de Teherán es responsable por la seguridad de los rehenes [...]. La estrategia norteamericana continúa siendo la de "respuesta gradual", es decir, contestar rápidamente a cada acción de los revolucionarios iraníes con una contramedida que no ponga en peligro la vida de los rehenes. [...] Washington trata, con bastante éxito, aparentemente, de aislar a Irán en la comunidad internacional y obtuvo una notable victoria cuando consiguió impedir que se reuniera, a petición de Irán, el Consejo de Seguridad de la ONU ${ }^{53}$.

Otros ejemplos que respaldan tal aspecto los encontramos en informaciones que califican el comportamiento de Carter refiriéndose a una combinación "serenidad y firmeza", y que "le ha valido un fuerte apoyo de los norteamericanos y, si todo sale bien a largo plazo, podría influir en sus posibilidades de ganar la reelección en $1980^{\prime 54}$.

No hemos encontrado informaciones en las que se mencione la falta de apoyo de los organismos internacionales o de los países aliados, y sí alguna información en la que muestra el respaldo de la comunidad internacional al presidente norteamericano ${ }^{55}$.

Estados Unidos se convierte así en protagonista de la cobertura desde un posicionamiento ambiguo: por un lado, en cuanto a ensalzar la eficaz actuación del presidente demócrata, y por otro, al observarse cierta complacencia con los momentos que está atravesando el país norteamericano. El lenguaje denota a veces cierta satisfacción porque Estados Unidos esté sufriendo un duro revés y se convierta en una

\footnotetext{
52 Aunque la cita es larga, consideramos su inclusión de interés: « [...] 'No están solos, y se lo hacemos saber', afirman los manifestantes, con expresiones graves y determinadas, refiriéndose a los estudiantes islámicos que ocupan la embajada. Vienen en familia, el hombre generalmente vestido modestamente, dando la mano a un hijo y en la otra una efigie del 'guía'. La mujer, totalmente recubierta con un chador negro y un niño en los brazos. Los desfiles surgen repentinamente, avanzan despacio, salmodiando las mismas consignas, mientras los altavoces difunden música revolucionaria. La calle se llena de gente una vez más. Y ya, cuando el cortejo parece estar a punto de acabarse, nuevas banderolas anuncian la próxima manifestación. En el crepúsculo se encienden numerosas hogueras, y la gente se apiña para discutir durante horas y horas antes de dormirse envuelta en mantas. Al alba, los últimos manifestantes se dispersan, mientras que los que han optado por el sueño se acercan aún más a las brasas incandescentes o se refugian en los portales y pasillos de las casas adyacentes». "Un día en las cercanías de la embajada", El País, 15-11-1979, p. 3.

${ }^{53}$ GONZÁLEZ, JUSTE, J. "Washington intenta aislar diplomáticamente a Teherán”, El País, 16-11-1979, p. 1.

54 BAYÓN, F. "Favorable acogida en Washington al anuncio de la liberación parcial de los rehenes", El País, 18-11-1979, p. 2.

${ }^{55}$ FUSH, A., "La banca suiza aplaude la decisión de Carter”, El País, 16-11-1979, p. 3.
} 
potencia vencida: "Los intereses norteamericanos sufrieron ayer un nuevo y humillante golpe, cuando grupos musulmanes incendiaron la embajada estadounidense en Pakistán. Un cabo de marines resultó muerto en el ataque" ${ }^{56}$.

Cinco rehenes de la embajada de Estados Unidos en Teherán fueron liberados ayer. Ninguno de ellos es de nacionalidad norteamericana -dos son filipinos, uno surcoreano, otro bengalí y, finalmente, un paquistaní-, con lo que en manos de los estudiantes islámicos ya sólo quedan súbditos de nacionalidad estadounidense $e^{57}$.

Si en $A B C$ los estadounidenses recibían una crítica por la debilidad moral o la incapacidad de control en situaciones límite con respecto a las informaciones sobre los primeros rehenes liberados, El País adoptó un tono diferente para abordar el tema: "Unas y otros se abrazaban y reían con grititos nerviosos. Un joven estudiante islámico barbudo interrumpiría tanta efusión para dar comienzo a una rueda de prensa en la que poco más se pudo saber sobre las reales condiciones de internamiento de los rehenes ${ }^{\prime \prime 5}$. Parece que quisiera recrearse en la humillación a la que han sido sometidos y describir un estereotipo concreto y mayormente negativo del pueblo norteamericano:

Dos recios sargentos y una gordezuela secretaria de ojos azules fueron los tres primeros funcionarios de la embajada de Estados Unidos en Teherán, puestos en libertad por los estudiantes islámicos seguidores del ayatollah. El redondo y rosado rostro de Kathy se sonrojó ante una pregunta: ¿qué le diría al presidente Carter? "No sé qué le diría...". Contestó avergonzada del protagonismo adquirido en tan pocas horas. [...] "Qué piensas del imperialismo?" -le preguntó un periodista iraní al sargento Quarles-. "La gente, contestó Quarles, debería ver las dos caras de la moneda. Durante estas dos últimas semanas hemos tenido la oportunidad de ver la otra cara de la política norteamericana'. [...] qué es lo que los iraníes deberían hacer con los espías? preguntó otro periodista iraní, '¿con los espías? No sé, pienso que habría que meterlos en la cárcel, no sé, sí, en la cárcel159.

Nos ocupamos a continuación del análisis de los editoriales. El primero de ellos califica el tema como de "excepcionalmente grave", denunciando la "ocupación" y el "asalto" de la embajada norteamericana. Se refieren a Carter como una figura "vacilante y borrosa" y advierten en considerar que estamos ante una "tiranía teológica". El discurso, por tanto, no sólo no se asemeja a lo expuesto desde los otros elementos

\footnotetext{
${ }^{56}$ BAYÓN, F. “Irán no aceptará dólares por su petróleo", El País, 22-11-1979, p. 1.

57 "Los rehenes no norteamericanos de la embajada en Irán, liberados", El País, 23-11-1979, p. 1.

${ }^{58}$ BAYÓN, F. "Trece rehenes liberados en Teherán", El País, 20-11-1979, p. 1.

59 BAYÓN, F. "Rueda de prensa de los primeros liberados de la embajada de EE.UU.", El País, 20-11-1979, p. 2.
} 
informativos, sino que lo contradice de forma rotunda. Estamos ante una "[...] revolución descabellada en su forma y en sus objetivos (la implantación de una tiranía teológica, las ejecuciones sumarias, el exterminio de las minorías, el germen de la guerra santa) $[\ldots]^{\prime \prime 0}$.

Si desde el primer editorial se denunciaba la gravedad de los hechos, sin entrar a responsabilizar a Estados Unidos en los mismos, en el segundo se detectan ciertos rasgos de gravamen contra el país norteamericano. Ofrecemos, no obstante, una interpretación imprecisa por cuanto no hay una claridad expositiva y sí algunos elementos retóricos que muestran una descripción confusa como se desprende del siguiente extracto:

Detrás de la rudeza, de la violencia con que se está desarrollando la crisis entre Estados Unidos e Irán, y de términos mayores, como es la declaración por Carter del estado de emergencia nacional, parece vislumbrarse el tema de ambas dos partes por llevarla demasiado lejos [...]. Parece que la respuesta de Carter, al renunciar a la adquisición de petróleo iraní y al bloquear los fondos del Gobierno de Teherán antes de que éste cumpliera su amenaza de transferirlos a países extranjeros, no solamente tiene la intención de evitar el nuevo descenso del dólar en los mercados internacionales y de suponer una cierta cobertura de los rehenes, sino que también permite a Estados Unidos recuperar una cierta iniciativa, que había perdido desde el principio de la crisis. [...] El caso de la Embajada de Teherán es solamente la punta emergente de un iceberg, cuyas cuatro quintas partes están sumergidas. Si la anécdota ofrece un riesgo inmediato, lo más grave es que la otra crisis, la profunda, apenas ha hecho más que empezar ${ }^{61}$.

Con respecto al tercer y último editorial coincide en parte con el discurso expuesto desde los otros géneros y elementos analizados, es decir, con un enérgico y contundente Jimmy Carter, tan prudente como capaz de ordenar una intervención militar que sí pondría en grave peligro el orden mundial. Aunque El País no se aísla de la condena hacia el régimen de Jomeini, ésta no es tan explícita como la de los otros diarios.

El largo asalto a la embajada estadounidense en Irán es condenable internacionalmente por cuanto, pese al poderío estadounidense, consagra la presunta validez del principio de fuerza en la negociación diplomática. Mal que les pese, las turbas del ayatollah Jomeini, no están haciendo valer principios de mesianismo islámico de "justicia popular" o de revolucionarismo utópico: están

\footnotetext{
60 “Irán, la revolución en expansión”, El País, 08-11-1979, p. 8, (editorial).

61 “La crisis de Irán”, El País, 17-11-1979, p. 6, (editorial).
} 
haciendo valer el principio del chantaje por medio de la fuerza bruta y de los hechos consumados. [...] La ya prolongada detención, contraria a derecho, de los ciudadanos norteamericanos y la pretensión de "legalizar" ese secuestro con un procesamiento por espionaje podría forzar al Gobierno norteamericano, tan dependiente siempre de la opinión pública, y más aún en un año de elecciones presidenciales, a decisiones militares cuyas consecuencias son imposibles de calcular y que, por tanto, no excluyen el desencadenamiento de un conflicto a escala mundial ${ }^{62}$.

\section{Conclusiones}

La actitud de la prensa española sobre los hechos, ofrece, con la perspectiva que brindan tres décadas, una interesante descripción e interpretación de los mismos. Es sugestivo comprobar cómo algunos puntos de vista que enunciaron entonces continúan vigentes. En el discurso de La Vanguardia lo prioritario fue resaltar la amenaza de la revolución islámica, es decir, lo que consideró era el centro de la crisis y sus posibles consecuencias, y así lo hizo desde todos los elementos incluidos. El experimento político que suponía el nacimiento de un fenómeno religioso y revolucionario de estas características y sujeto a alteraciones profundas, era un peligro grave para el débil equilibrio mundial. Para el rotativo catalán, se acababa de iniciar una guerra en un mundo cobarde e ineficaz por culpa de organismos internacionales que respaldaban con su silencio los acontecimientos. Irán, a la luz de los hechos, no podía ser considerada como una nación civilizada. La gestión de la crisis fue objeto de una lacerante y sarcástica condena. En primer término, por la irresponsabilidad de Jomeini y sus fanáticos seguidores, y en segundo lugar, por un vacilante Carter, su peregrina doctrina de los Derechos Humanos, y unos aliados pusilánimes, incapaces de pronunciarse ante la llegada de un movimiento peligroso.

$A B C$ dedicó bastante protagonismo a Estados Unidos, tanto por dar origen a la crisis por su respaldo al Sha, como por no ser capaz de controlar los acontecimientos una vez desatados. Sus preocupaciones argumentales se centraron en los orígenes y causas de la revolución, y en la gestión norteamericana de la misma. Carter absorbió en el diario la responsabilidad de haber colocado a los Estados Unidos en un nivel tan marginal desde el punto de vista internacional. La gravedad de esta crisis arroja dos lecturas: el nacimiento del terrorismo de Estado y la pérdida de influencia de los Estados Unidos. Subyace en la cabecera, el trasfondo antiamericano de la crisis: se

\footnotetext{
62 “El síndrome de Teherán”, El País, 05-12-1979, p. 8, (editorial).
} 
trata de ir contra todo lo que represente Estados Unidos. El desequilibrio de fuerzas permitía el triunfo de la revolución de Jomeini: el imán chí́ta abusaba del poder, y el presidente demócrata era incapaz de usarlo.

$L a$ Vanguardia y $A B C$ coincidieron en sus discursos y en los tiempos, es decir, fueron relatando cómo evolucionaba la crisis, mientras analizaban los orígenes y las consecuencias en torno a los mismos argumentos y a la propia actualidad. Ambos diarios se hicieron eco de una "guerra santa" o de un "terrorismo de Estado", y ambos compartieron una cobertura en la que combinaron las tres operaciones discursivas: descripción, interpretación y evaluación, con mayor presencia de las dos últimas.

La Vanguardia anticipó el polvorín en que se convertía el golfo Pérsico a partir de ese momento, así como las alteraciones profundas que suponía un fenómeno religioso con gran capacidad desde el punto de vista político. Si bien, el foco argumental más evidente es la desafección que siente por la revolución chiíta. $A B C$ siente una profunda decepción por el comportamiento de los Estados Unidos: la crítica al respecto es contundente. Las líneas de opinión, estructura y lenguaje empleados por ambos rotativos son uniformes, y los argumentos claros. Los dos aciertan en su análisis al anticipar hechos que se han comprobado.

Las conclusiones en El País arrojan cierta ambigüedad discursiva, tanto argumental como de forma. Hay una coincidencia con $A B C$ al centrar la atención en la humillación sufrida por los Estados Unidos, sin embargo observamos una discrepancia con la cabecera madrileña en cuanto a que dicha humillación no parece motivo de crítica ni de preocupación. Acomete discursos diferentes desde las primeras páginas, las crónicas y los editoriales, lo que dificulta la identificación de una actitud concreta, si bien, parece más condescendiente con los hechos y con los protagonistas de los mismos: EE.UU., Carter y Jomeini. Las operaciones discursivas se caracterizan por una mayor presencia de evaluación, menos o casi inexistente de interpretación y una descripción de los hechos caracterizada por una equiparación de igual a igual entre Irán y Estados Unidos sin que se perciba una distinción explícita entre agresores y víctimas. En el mismo sentido, detectamos en líneas generales, una ausencia de condena y de crítica, tanto hacia la gestión estadounidense como hacia la agresión encabezada por Jomeini. El diario no aclara sus argumentos, adorna datos anecdóticos, rebaja la gravedad de los hechos sin profundizar en lo importante de la información. Describen a un Carter firme, mientras elogian su pusilanimidad y su debilidad ante la crisis. Sus líneas de opinión son contradictorias y los elementos discursivos que emplea así lo confirman. Anunció que Estados Unidos llevaría a cabo una intervención militar; no fue en sí una intervención, sino más bien un intento de liberación, se llamó "Desert One", ocurrió en abril de 1980, y fue un fracaso rotundo.

La cobertura periodística que se lleva a cabo sobre los hechos que se suceden en Oriente Próximo presenta, en ocasiones, la realidad de forma interesada y hasta cierto 
punto, irresponsable. Un deficiente trabajo informativo puede ejercer un impacto negativo sobre la opinión pública, y ésta, puede practicar una influencia notable en las decisiones de los gobiernos e incluso en los resultados electorales. Algunos ejemplos que ilustran esta certeza nos retrotraen al Irán de hace treinta años, pasando por las dos guerras en el Golfo Pérsico e incluso a la actual Siria. 


\section{Anexo: Imágenes publicadas en los diarios de análisis}

Figura 1. Fotografías de las portadas en La Vanguardia
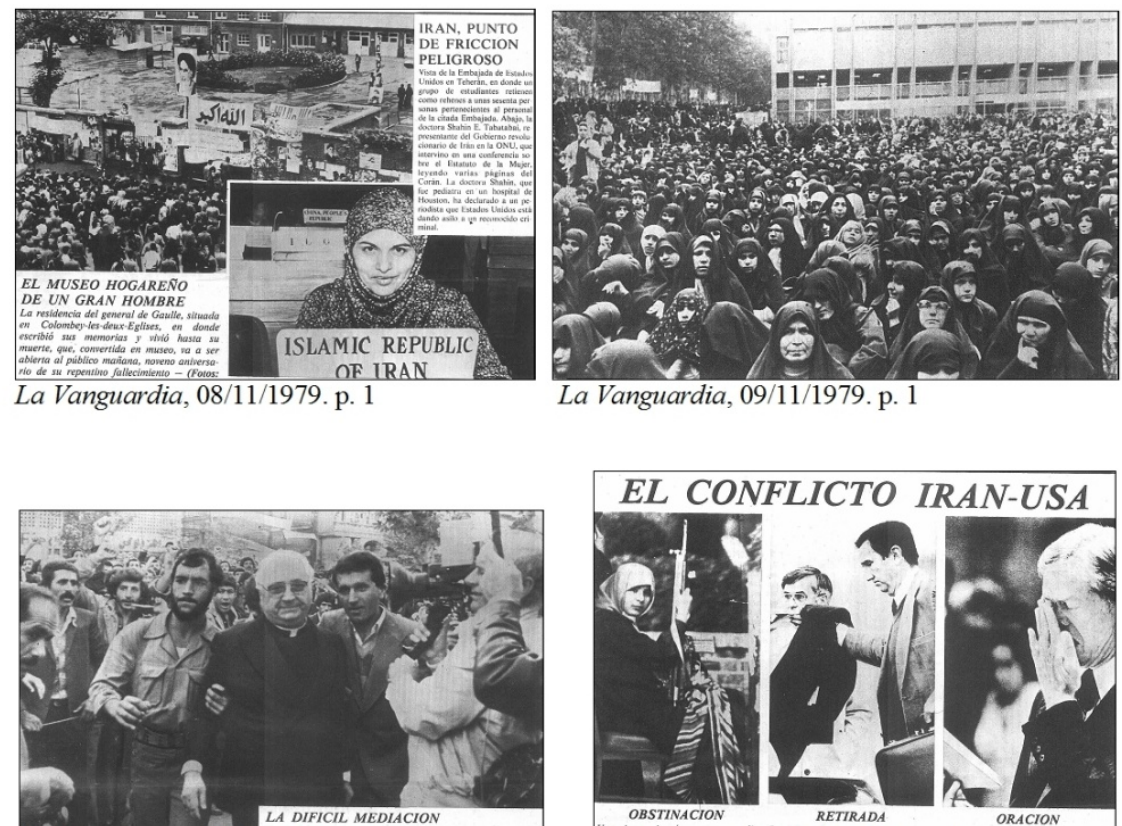

La Vanguardia, 15/11/1979. p. 1
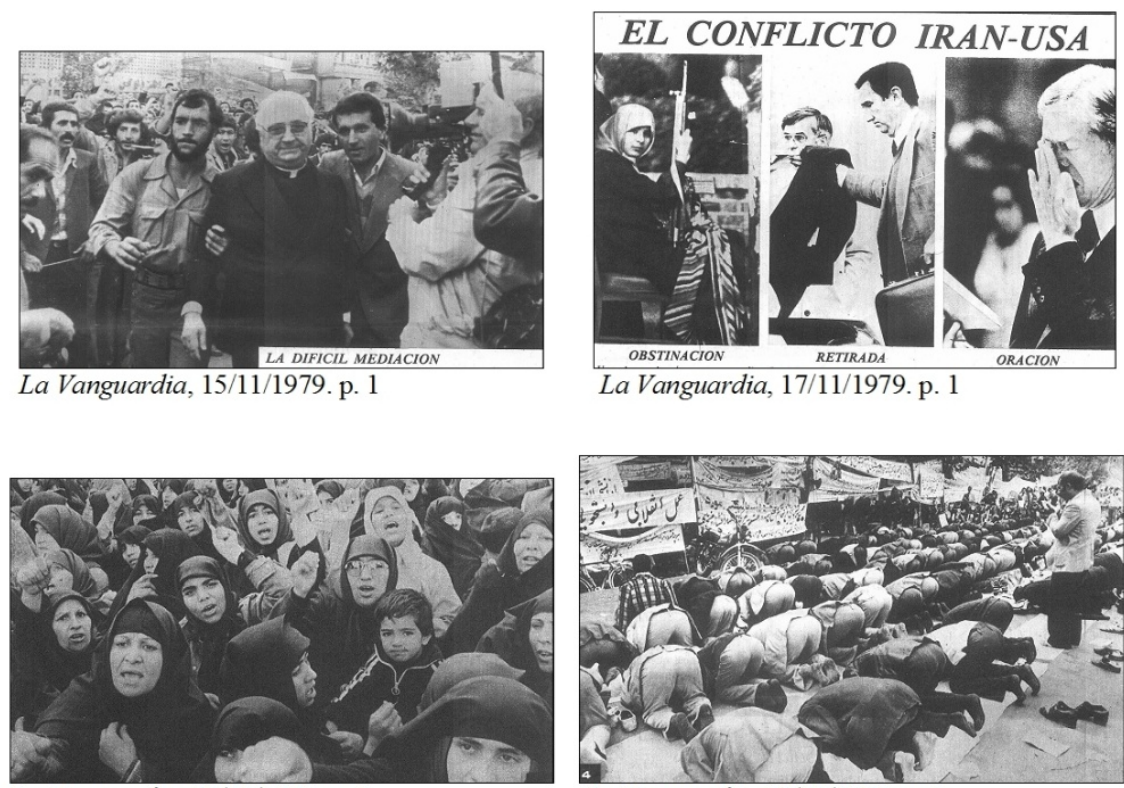

La Vanguardia, 22/11/1979. p. 1

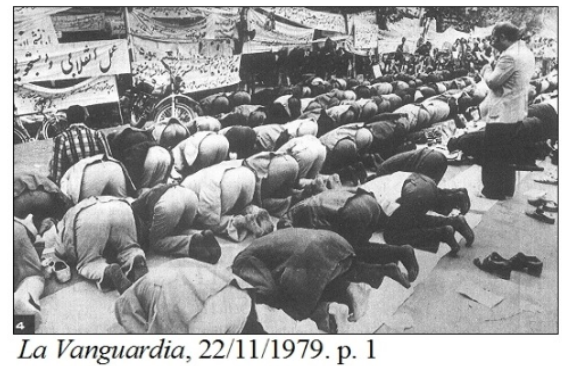


Figura 2. Fotografías de las portadas en $A B C$

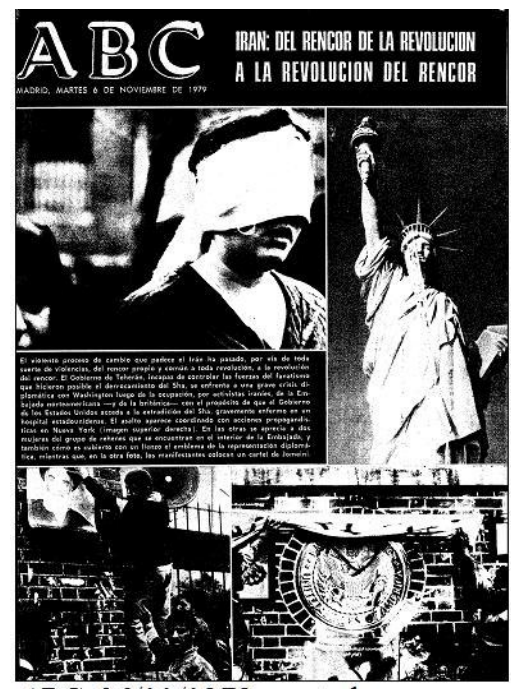

$A B C, 06 / 11 / 1979$, portada.

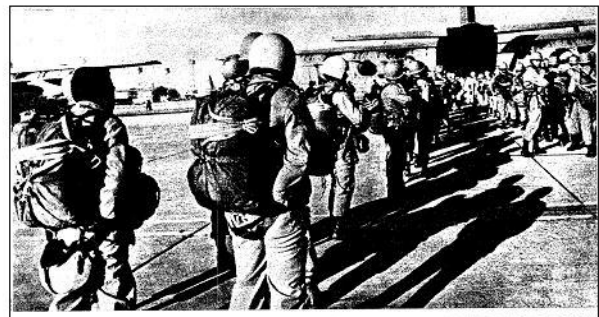

IRAN: MOUIMIENTOS DE TROPAS EN EI GOLFO PERSICO $A B C, 28 / 11 / 1979$, portada. 
Figura 3. Fotografías de las portadas en El País

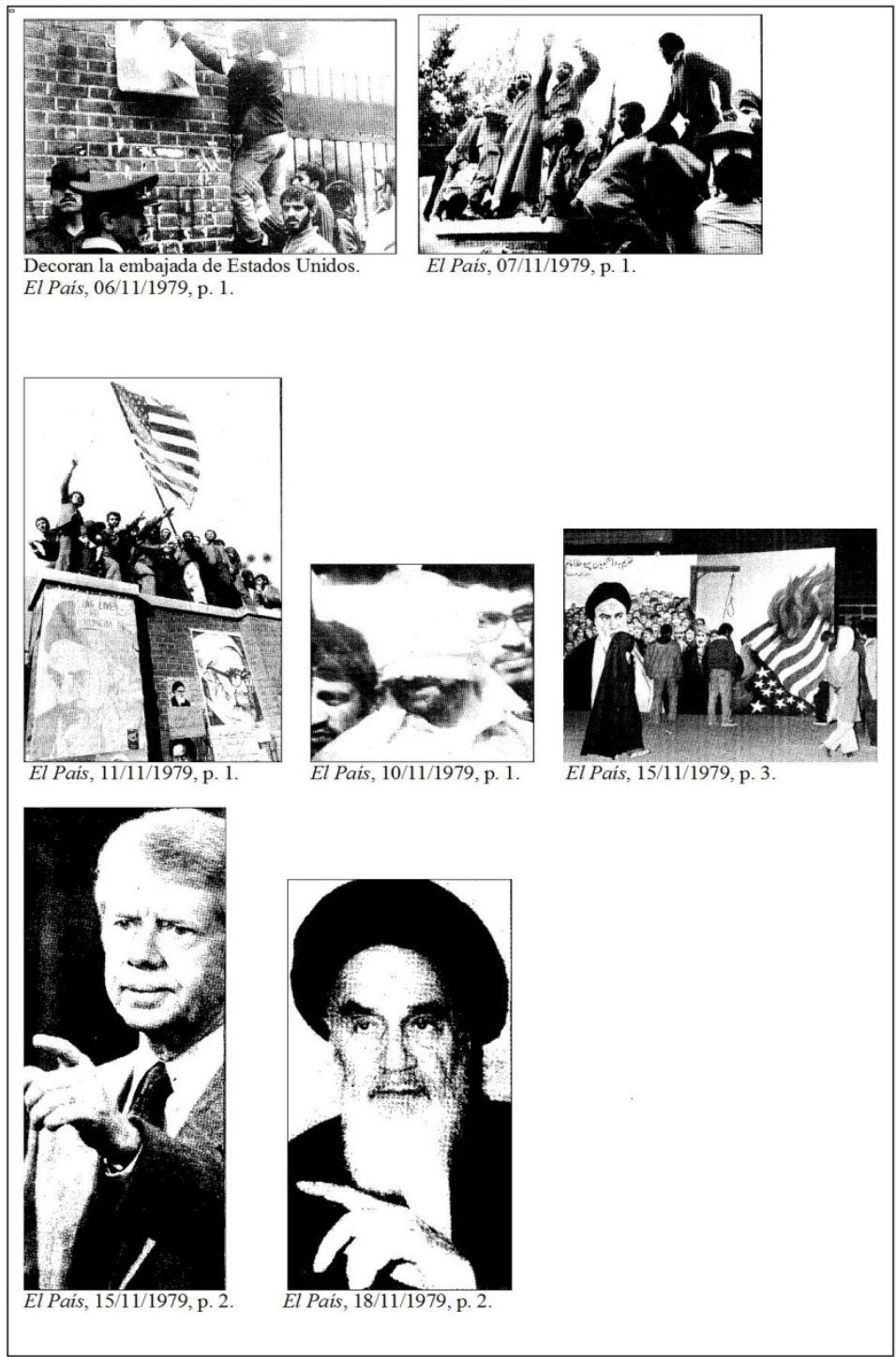

Figura 4. Viñeta publicada en El País
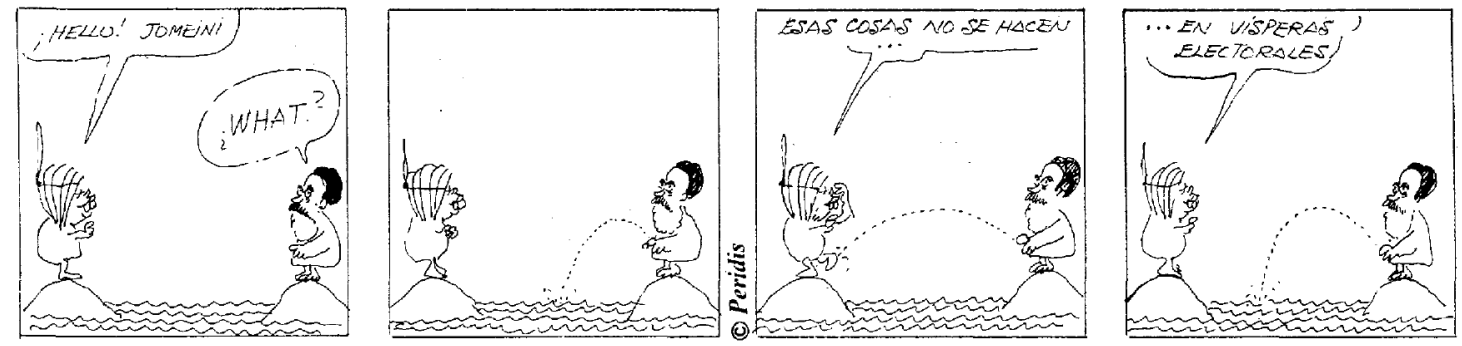

El País, 10/11/1979, p. 3. 


\section{Referencias bibliográficas}

ÁLVAREZ-OSORIO, I. (2007): "Europa e Islam: ¿alianza o conflicto?”, en VERES, L., ABRIL STOFFELS, R. (eds): Entre la cruz y la media luna: Islam y seguridad europea, Valencia, De la Torre, pp. 129-144.

- (2006): "El mundo árabe: entre la tradición y la modernidad", en Cuadernos Bakeaz de Geopolítica, no 73, pp. 1-16.

- (2004): “25 Años de Revolución Islámica”, en Clío: Revista de Historia, no 29, pp. 26-33.

DREYFUSS, R. (2005): Devil's Game. How the United States Helped Unleash Fundamentalist Islam, Nueva York, Metropolitan books.

EBADI, S. (2007): El despertar de Irán: memorias de revolución y esperanza, Madrid, Aguilar.

FARZAMNIA, N. (2009): Irán. De la Revolución Islámica a la Revolución Nuclear, Madrid, Síntesis.

FRAILE ALONSO, M. (2009): “¿Cómo se "perdió" Irán?: Una visión global del contexto histórico a 30 años de la caída del Sha", en Isagogé, no 6, pp. 48-53.

FRENKEL, L. (1981): "La Constitución de la república islámica de Irán", en Revista de Estudios Políticos, no 20, pp. 105-117.

HEIKAL, M. (1982): El regreso del Ayatollah: la revolución iraní de Mossadeq a Jomeini, Barcelona, Argos Vergara.

MARTÍN MUÑOZ, G. (2000): “Irán: Islamismo y democracia”, Política exterior, Vol. 14, № 73,2000, pp. $27-36$.

MARTíN, J. (2005): Hizbullah, el brazo armado de Dios, Madrid, Catarata.

MARTÍNEZ HOYOS, F. (2002): "Irán la revolución de Jomeini”, en Historia y vida, no 415, pp. 16-19.

MOODY, S. C. and the News Staff and photographers of The Associated Press (1981): 444 days. The American hostage story, New York, Rutledge Press.

RODRÍGUEZ, J. M. (1988): “Jomeini, la cólera de Alá. Biografía de un predestinado", en Historia 16, no 144, pp. 49-63.

SCHOLL-LATOUR, P. (1984): Alá es grande. Encuentros con la revolución islámica, Barcelona, Planeta. 
SICKMANN, R. (1982): Iranian hostage: a personal diary of 444 days in captivity, Topeka, Crawford Press.

SIEFF, M. (2008): The Politically Incorrect Guide to the Middle East, Washington, D.C., Regnery.

THOMPSON, J. B. (1998): Los medios y la modernidad, Barcelona, Paidós.

(1990): Ideology and modern culture: critical social theory in the era of mass communication, Cambridge, Polity Press.

WELLS, T. (1985): 444 days: the hostages remember, San Diego, Harcourt Brace Jovanovich. 